\title{
Antiamnesic and Neuroprotective Effects of Leaves of Mimusops Elengi on Brain Aging and Chemically Induced Amnesia in Mice
}

\author{
Hanumanthachar Joshi*, Charan CS and Majed Abdo Alkanad \\ Department of Postgraduate studies and Research, Neuroresearch Laboratory, Sarada Vilas College of Pharmacy, India
}

Received: April 12, 2018; Published: April 27, 2018

*Corresponding author: Hanumanthachar Joshi, Neuroresearch Laboratory, Department of Postgraduate studies and Research Sarada Vilas College of Pharmacy, KM Puram, Mysore-04, Karnataka, India

\section{Abstract}

Background: Memory loss is a most disabling feature of cognitive disorders which disrupts the life styles of patients and equally affects the patient caregivers. Management and treatment of memory loss is highly challenging as no potential remedy is available at present for the complete cure. In this study, antiamnesic and neuroprotective efficacy of methanolic extract of dried leaves of Mimusops Elengi Linn. (MEE) was investigated in mice.

Methods: Elevated plus maze and Morris water maze were used for assessment of acquisition and retention. Scopolamine (0.4mg/kg, i.p.) and diazepam $(1 \mathrm{mg} / \mathrm{kg}$, i.p.) induced amnesia were the exteroceptive models.

Results: MEE (100 and 200mg/kg, p.o.) significantly improved acquisition and retention in amnesic mice. MEE also exhibited reversal effects in aged mice (aging induced amnesia). MEE significantly increased acetyl cholinesterase inhibitory activity in the mouse brain. M. Elengi exhibited potential neuroprotective effects.

Conclusion: Methanolic extract of $M$. Elengi can prove to be a potential cognition improving agent which can be beneficial in management of various cognitive disorders found in elderly.

Keywords: Acetyl Cholinesterase; Mimusops Elengi; Memory Loss; Scopolamine

\section{Introduction}

In the present study, the nootropic and antiamnesic effects of methanolic extract of Mimusops Elengi (MEE) has been studies by employing both exteroceptive and interoceptive models in mice. Elevated plus maze is a neutral exteroceptive model used to assess short-term memory and Morris water maze is used to test long-term memory. Interoceptive behavioural models such as scopolamine, diazepam and natural aging induced amnesia are widely used experimental models simulating dementia in human [1]. Mimusops Elengi L. [Sapotaceae] is known as bakula in ayurveda [2]. It is a small to large evergreen tree found all over India and is cultivated in gardens as an ornamental tree and is used in the ayurvedic system of medicine for the treatment of various neurological disorders [34]. Stem bark of Mimusops Elengi possesses cardiotonic, stomachic, anthelmentic and astringent properties [5]. The bark powder along with 50g alum, $5 \mathrm{~g}$ sodium chloride, is warmed and used for massaging on teeth in the treatment of pyorrhea by the locals [6]. The fine powder is sniffed to relieve headache, the decoction is used as a general tonic and flower in perfumery [7]. Phytochemical review of the bark of M. Elengi reveals the presence of taraxerol, taraxerone, ursolic acid, betulinic acid, quercitol, lupeol [8], alkaloid isoretronecyl tiglate and mixture of triterpenoid saponins [9-10]. M. Elengi is reported to possess anti-ulcer [11] and hypertensive [12], bark improved memory in mice [13] and flowers enhanced cognition in rats [14]. The leaves are well known for analgesic, antipyretic, antioxidant and anti inflammatory properties [1517]. The present study was undertaken to evaluate the effects of methanol extract of leaves of $M$. Elengi on scopolamine and ageing induced amnesia in mice.

\section{Materials and Methods}

The leaves of Mimusops Elengi were collected from mature trees growing in the forests of chamundi hills, Mysore, Karnataka during flowering season and identified by experts at Govt. Ayurvedic Medical College and Research Center, Mysore. The leaves were cleaned, shade dried and powdered. One kilogram of moderately 
powdered leaves was extracted by refluxing with methanol in soxhlet extractor for 8-10 h. The extract was evaporated to dryness under reduced pressure and temperature using rotary vacuum evaporator. The yield of dry extract from the crude powder was $16 \% \mathrm{w} / \mathrm{w}$. The methanol extract was suspended in a mixture of Tween 80: Distilled Water in a ratio of 2:8. The suspension was orally administered to animals. The volume of administration was $1 \mathrm{ml} / 100 \mathrm{~g}$, body weight of mice.

\section{Drugs and Reagents}

Scopolamine hydro bromide (Sigma Aldrich, USA), diazepam

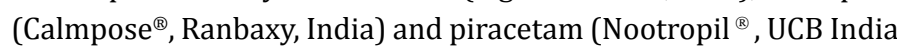
Pvt. Ltd., India) were diluted in normal saline and administeredintra peritoneally. Volume of administration was $1 \mathrm{ml} / 100 \mathrm{~g}$. All the drugs were administered in the morning session i.e. $8 \mathrm{AM}-9 \mathrm{AM}$ on each day. 5, 5'-dithiobis nitrobenzoic acid (DTNB, Ellman's reagent, Sigma, USA) and acetyl thiocholine (Sigma, USA) were used.

\section{Animals}

Swiss mice of either sex weighing around 18- $20 \mathrm{~g}$ (younger ones, aged 3-4 months) and more than $30 \mathrm{~g}$ (aged ones, aged 12-15 months) were used in the present study. Animals were acclimatized to the laboratory conditions for 5 days before behavioral studies. The animals had free access to food and water and were maintained under 12:12 h light and dark cycles. All experiments were carried out during day time from 0900 to $1400 \mathrm{~h}$. Institutional Animals Ethics Committee (IAEC) had approved the experimental protocol and care of animals was taken as per guidelines of CPCSEA, Dept. of Animal Welfare, Govt. of India.

\section{Acute Toxicity Studies}

M. elengi methanolic extract (MEE) at different doses (10$2000 \mathrm{mg} / \mathrm{kg}$ ) was administered orally to mice with the help of a specially designed oral needle connected to a polythene tube. AR was administered at the same time on each day (i.e. 8 AM- 9 $\mathrm{AM}$ ). During the first four hours after the drug administration, the animals were observed for gross behavioral changes if any, for 7 days. The parameters such as hyperactivity, grooming, convulsions, sedation, hypothermia and mortality were observed. The doses selected were 100 and $200 \mathrm{mg} / \mathrm{kg} /$ day.

\section{Elevated Plus-maze}

Elevated plus-maze served as the exteroceptive behavioral model to evaluate learning and memory in mice. The procedure, technique and end point for testing learning and memory was followed as reported earlier [18-20]. The elevated plus maze for mice consisted of two open arms [16 $\mathrm{cm} \times 5 \mathrm{~cm}]$ and two covered arms $[16 \mathrm{~cm} \times 5 \mathrm{~cm} \times 12 \mathrm{~cm}]$ extended from a central platform $[5 \mathrm{~cm}$ $\times 5 \mathrm{~cm}$ ], and the maze was elevated to a height of $25 \mathrm{~cm}$ from the floor. On the first day, each mouse was placed at the end of an open arm, facing away from the central platform. Transfer latency [TL] was defined as the time taken by the animal to move from the open arm into one of the covered arms with all its four legs. TL was recorded on the first day for each animal. The mouse was allowed to explore the maze for another 2 minutes and then returned to its home cage. Retention of this learned-task was examined $24 \mathrm{~h}$ after the first day trial.

\section{Morris Water Maze (MWM)}

The MWM test was employed to assess learning and memory of the animals. MWM is a swimming model where the animals learn to escape on to a hidden platform. In the present study the target quadrant was Q4. The mice were subjected to 4 consecutive trials every day with a gap of 5 minutes for 7 days continuously, during which they were permitted to escape to the hidden platform and to be remained for $20 \mathrm{sec}$. If the animal was not able to find the hidden platform within 120 seconds, the mouse was gently pushed and guided to the platform and permitted to stay on the platform for further 20 seconds. Escape latency time to identify the hidden platform in Morris water maze was the index of acquisition (learning)[21]. The starting point on every day to conduct 4 acquisition trials was changed as described below and Q4 was maintained as the target quadrant in all the acquisition trials. The starting point for dropping the mice into water maze on day 1 for four consecutive acquisition trials was in the sequence Q1, Q2, Q3 Q4 and so on.

The sequence change in starting point was as follows. Day 1: Q1, Q2, Q3, Q4 Day 2: Q2, Q3, Q4, Q1 Day 3: Q3, Q4, Q1, Q2 Day 4: Q4, Q1, Q2, Q3. Mean escape latency time (ELT) was calculated for each day of the trial. On the $8^{\text {th }}$ day the hidden platform was removed, each mouse was permitted to explore the pool for 120 seconds. The animal was made to take 4 such trials with 5 -minute interval time and every trial had a different starting point covering all the 4 quadrants. The mean of time spent by the animal in all 4 quadrants was recorded. The TSTQ (time spent in target quadrant) in Q4 as compared to time spent in other quadrants in locating missing platform was considered as an index of retrieval (memory). Utmost care was employed to ensure that relative location of water maze with respect to any other objects in the laboratory serving as visual clues was not disturbed during the total duration of the study. All the trials were completed between 09:00 and 17:00 hours [22].

\section{Scopolamine Induced Amnesia}

Amnesia was induced by administration of scopolamine hydro bromide $\left(0.4 \mathrm{mg} / \mathrm{kg}\right.$, ip) on $8^{\text {th }}$ day and the TL recorded. Retention was recorded after $24 \mathrm{hr}$. MEE (100 and $200 \mathrm{mg} / \mathrm{kg}$, po) and piracetam $(200 \mathrm{mg} / \mathrm{kg}$ ) were administered for 7 days successively. On $7^{\text {th }}$ day, after 45 min of administration of doses, scopolamine was administered and TL was noted after $45 \mathrm{~min}$. SDL was recorded on $8^{\text {th }}$ day [23-25].

\section{Diazepam Induced Amnesia}

Diazepam, $1 \mathrm{mg} / \mathrm{kg}$, ip was administered to young mice and TL was noted after 45 min of injection on $7^{\text {th }}$ day and after $24 \mathrm{hr}$. MEE (100 and $200 \mathrm{mg} / \mathrm{kg}$, po) and piracetam $(200 \mathrm{mg} / \mathrm{kg}$, i.p.) were administered for 7 successive days. After $60 \mathrm{~min}$ of administration of the last dose on $7^{\text {th }}$ day, diazepam ( $1 \mathrm{mg} / \mathrm{kg}$, ip) was administered. TL was noted after 45 min of administration of diazepam and after $24 \mathrm{hr}$. SDL was recorded on $8^{\text {th }}$ day [26-27]. 


\section{Estimation of Brain Acetyl Cholinesterase (AChE) Activity}

The time frame of cholinesterase activity estimation was similar to behavioral tests i.e. $8 \mathrm{AM}-11 \mathrm{AM}$ on each day. On the $8^{\text {th }}$ day the animals were euthanized by cervical dislocation carefully to avoid any injuries to the tissue. The whole brain AChE activity was measured spectroscopically using the Ellman method [28].

\section{Statistical Analysis}

All the results were expressed as mean \pm Standard error. The data was analyzed using ANOVA followed by Tukey-kramer test.

\section{Results}

\section{Acute Toxicity Study}

No mortality was observed following oral administration of MEE even with the highest dose $[2000 \mathrm{mg} / \mathrm{kg}]$. MEE had no toxic effect on the normal behavior of the mice. However doses more than $1500 \mathrm{mg} / \mathrm{kg}$ exhibited profuse watery stools.

\section{Effect on Transfer Latency (TL) using Elevated Plus Maze}

Aged mice showed higher transfer latency (TL) values on first day and on second day (after $24 \mathrm{hr}$ ) as compared to young mice, indicating impairment in learning and memory (i.e. ageinginduced amnesia). Piracetam $(200 \mathrm{mg} / \mathrm{kg}$, ip) pre-treatment for 7 days decreased transfer latency on $7^{\text {th }}$ day and after $24 \mathrm{hr}$, i.e. on $8^{\text {th }}$ day as compared to distilled water treated group, indicating improvement in both learning and memory. Scopolamine $(0.4 \mathrm{mg} /$ $\mathrm{kg})$ and diazepam $(1 \mathrm{mg} / \mathrm{kg})$ increased TL significantly $(\mathrm{P}<0.01)$ in young mice on first and second day as compared to control, indicating impairment of memory (Figure 1). MEE (100 mg/kg, po) decreased the TL on $7^{\text {th }}$ day and $8^{\text {th }}$ day in young and aged mice $(\mathrm{P}<$ $0.05)$ when compared to control groups. MEE (200mg/kg, po) more significantly enhanced the learning and memory of aged animals rather than the young mice as reflected by marked decrease in $\mathrm{TL}$ on $7^{\text {th }}$ day and $8^{\text {th }}$ day when subjected to elevated plus maze tests (Figure 1). MEE $(200 \mathrm{mg} / \mathrm{kg}$, po) pretreatment for 7 days successively protected young mice $(\mathrm{P}<0.001)$ against scopolamine, diazepam and ageing induced amnesia (Figure 2).

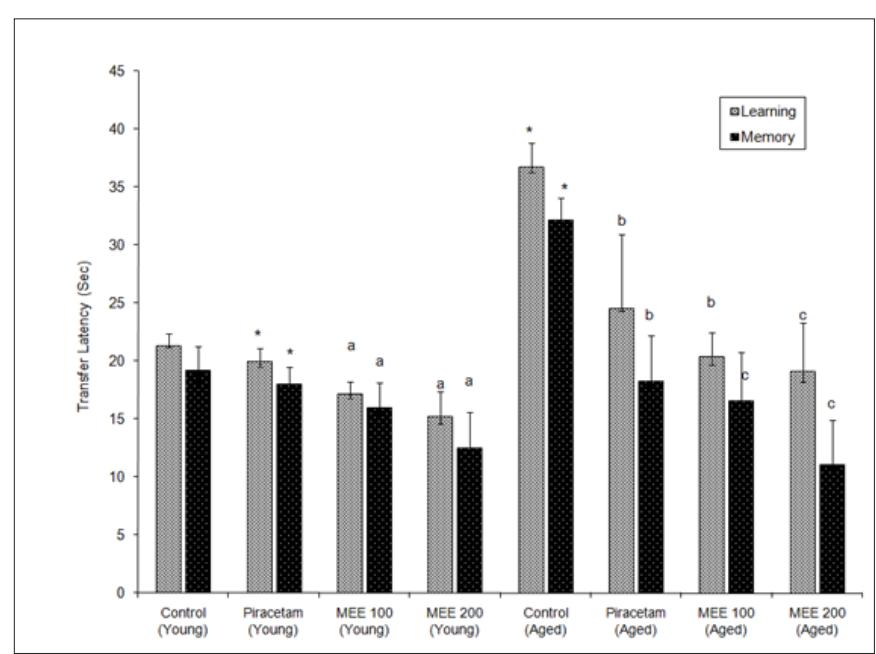

Figure 1: Effect of Mimusops Elengi (MEE) on transfer latencies of young and aged mice Values are mean \pm S.E.M. $(\mathrm{n}=6) ;{ }^{*}$ indicates $\mathrm{P}<0.01$ compared to control (young)

a indicates $\mathrm{P}<0.05$ compared to control (young ); $\mathrm{b}$ indicates $\mathrm{P}<0.05$ as compared to control (aged);

c indicates $\mathrm{P}<0.05$ compared to control (aged mice).

Effect on Escape Latency Time (ELT) using Morris Water Maze

In MWM extreroceptive model, ME $(100$ and $200 \mathrm{mg} / \mathrm{kg}$, po) exhibited significant fall in ELT as compared with control group which indicates the increase in acquisition ME $(200 \mathrm{mg} /$

Table 1: Effect of Mimusops Elengi (MEE) on Escape Latency time (ELT) \& Time Spent in TargetQuadrant (TSTQ) in aged mice.

\begin{tabular}{|c|c|c|c|}
\hline Drug & ELT ( $7^{\text {th }}$ day) & ELT (8 ${ }^{\text {th }}$ day) & TSTQ (9 ${ }^{\text {th }}$ day) \\
\hline Control & $97.02 \pm 0.12$ & $59.24 \pm 0.26$ & $53.00 \pm 0.2$ \\
\hline Piracetam (200 mg/kg, i.p.) & $77.02 \pm 2.5^{*}$ & $39.12 \pm 0.7^{*}$ & $59.12+2.3^{*}$ \\
\hline $\operatorname{MEE}(100$ mg/kg) & $82.36 \pm 3.1^{*}$ & $49.92 \pm 0.1^{* *}$ & $54.19 \pm 062^{* *}$ \\
\hline MEE (200mg/kg, P.O.) & $79.31 \pm 0.6^{* *}$ & $43.12 \pm 0.6^{* *}$ & $56.16 \pm 0.5^{*}$ \\
\hline
\end{tabular}

Each values represents mean+S.E.M. ${ }^{*} \mathrm{P}<0.01$ as compared to control, ${ }^{* *} \mathrm{P}<0.001$ compared to control. Oneway ANOVA followed by Tukey's post test. 


\section{Effect on whole Brain Acetyl Cholinesterase Activity}

The whole brain AChE activity raised significantly in mice treated with phenytoin $[12 \mathrm{mg} / \mathrm{kg}$, p.o.] as compared to control and piracetam [200mg/kg, p.o.]. MEE [100 and 200mg/kg, p.o.] significantly $[\mathrm{P}<0.001]$ lowered AChE activity indicating profound neuroprotection and improvements in memory (Figure 2).

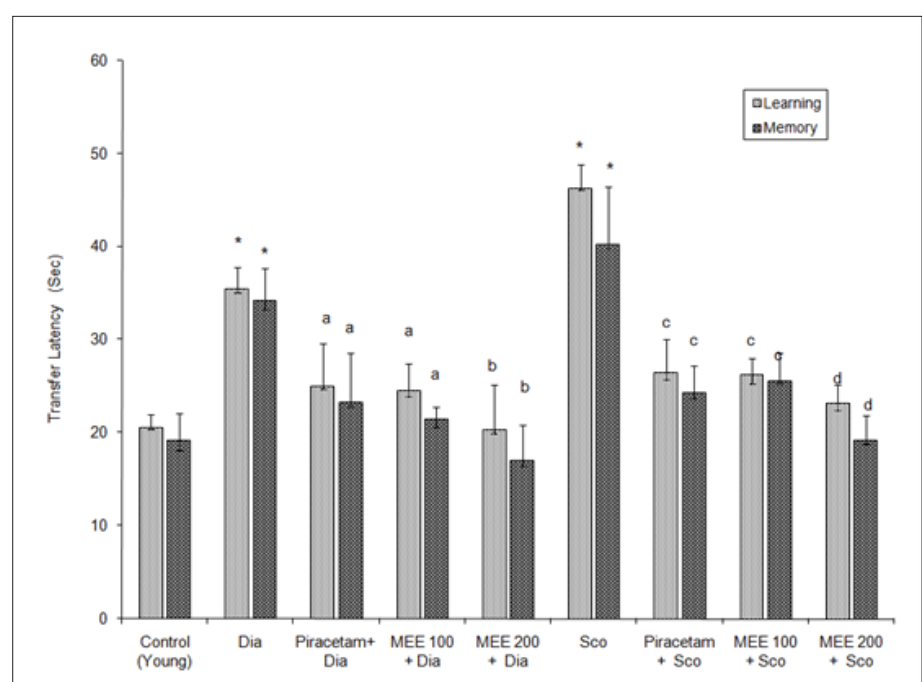

Figure 2: Effect of Mimusops Elengi (MEE) on transfer latency of diazepam and scopolamine induced amnesic mice. Values are mean \pm S.E.M. $(\mathrm{n}=6)$; * indicates $\mathrm{P}<0.05$ compared to control (young); a indicates $\mathrm{P}<0.05$ Compared to diazepam group; $\mathrm{b}$ indicates $\mathrm{P}<0.005$ compared to diazepam group. $\mathrm{c}$ indicates $\mathrm{P}<0.05$ compared to scopolamine group; d indicates $\mathrm{P}<0.001$ compared to scopolamine group.igure 3: Effect of Mimusops elengi (MEE) on whole brain cholinesterase (AChE) activity

Values are mean \pm S.E.M. $(\mathrm{n}=6)$; * indicates $\mathrm{P}<0.05$ compared to control (young)

a indicates $\mathrm{P}<0.05$ compared to control (young); b indicates $\mathrm{P}<0.05$ as compared to control (aged); c indicates $\mathrm{P}<0.05$ compared to control (aged mice).

\section{Discussion}

Cognitive disorders are majorly characterized by profound memory loss and inability to perform day to day normal activities which affect the life of an individual. There is sudden plunge in the incidence and prevalence of dementia across the world due to improved health benefits and increasing elderly community [29]. Despite of various advancements in science, the researchers are yet to find a radical remedy for cognitive dysfunctions. Few drugs are available such as Donepezil, rivastigmine, gallantamine but there usability for long time leads various adverse drug reactions and side effects [30]. Hence, research of phytopharmaceuticals obtained from medicinal plants of traditional origin can be beneficial. In this study, the methanolic extract of leaves of Mimusops elengi improved both acquisition and retention in mice afflicted with amnesia due to normal ageing, administration of scopolamine and diazepam, which indicated that MEE has excellent potential to be used as memory restorative agent in elderly.

\section{Acknowledgement}

The authors are thankful to the Rajiv Gandhi University of Health Sciences, Karnataka, and Bangalore for the research grant. Thanks are also due to UCB India Pvt. Ltd., Vapi, Gujarat, India for gift sample of piracetam.

\section{References}

1. Parle M, Dhingra D (2003) Ascorbic acid: a promising memory enhancer in mice. J Pharmacol Sci 93: 129-135.

2. Varrier PS (1997) Indian Medicinal Plants. Orient Longman, Madras, India.
3. Sharma PV (1987) Dravyaguna Vijnan: Medhya Varga, Varanasi, Chaukambha Bharati Academy, India.

4. Govindadasa (1884) Bhaisajyaratnavali, Varanasi, Chaukambha Sanskrita Academy, India.

5. Satyapala (1953) Kashyapasamhita, Chowkamba Prakashan, Varanasi, India.

6. Kirtikar KR, Basu BD (1935) Indian Medicinal Plants, Bishensingh Mahendra Pal singh, Dehradun, India.

7. Nadakarni KM (1993) Indian Materia Medica, Popular Prakashan, Bombay, India.

8. Misra G, Mitra CR (1968) Constituents of leaves, heart wood and root of Mimusops elengi. Photochemistry 7: 501-502.

9. Sahu NP, Koike K, Jia Z, Nikaido T (1997) Triterpenes saponins from Mimusops elengi. Photochemistry 44(6): 1145-1149.

10. Jahan N, Malik A, Mustafa G, Ahmad Z, Ahmad S, et al. (2001) Triterpenes from Mimusops elengi. Nat Prod Lett 15: 177-185.

11. Shah PJ, Gandhi MS, Shah MB, Goswami SS, Santani D (2003) Study of Mimusops elengi bark on experimental gastric ulcers. J Ethnopharmacol 89: 305-311.

12. Dar A, Behbahanian S, Malika A, Jahan N (1999) Hypotensive effect of the mehtanolic extract of Mimusops elengi in normotensive rats. Phytomedicine 6: 373-378.

13. Hanumanthachar Joshi, Milind Parle (2012) Reversal of memory deficits by ethanolic extract of Mimusops elengi Linn. in mice. Pharmacognosy Journal 29: 30-39.

14. Chitra V, Tamilanban T, Manasa K, Chitra K (2016) Cognitive and Anti Oxidant Property of Mimusops elengi Linn. in the Experimental Model of Alzhiemer's Disease in Rats. International Journal of PharmTech Research 9(3): 311-319. 
15. Manjeshwar SB, Ramakrishna JP, Harshith PB, Princy LP, Rekha B (2011) Chemistry and medicinal properties of the Bakul (Mimusops elengi Linn): A review. Food Res Int 44(7): 1823-1829.

16. Sakshi S, Vineet G, Rajiv G, Shubhini AS (2011) Analgesic and antipyretic activity of Mimusops elengi L. (bakul) leaves. Pharmacologyonline 3: 1-6.

17. Biswakanth Kar RB, Suresh Kumar, Indrajit Karmakar, Narayan Dola, Asis Bala, et al. (2012) Antioxidant and in vitro anti-inflammatory activities of Mimusops elengi leaves. Asian Pacific Journal of Tropical Biomedicine 2(2): 976-980.

18. Itoh J, Nabeshima T, Kameyama T (1990) Utility of an elevated plus maze for the evaluation of nootropics, scopolamine and electro convulsive shock. Psychopharmacology 101(1): 27-33.

19. Biradar SM, Joshi H, Chheda TK (2012) Neuropharmacological effect of Mangiferin on brain cholinesterase and brain biogenic amines in the management of Alzheimer's disease. Eur J Pharmacol 683(1-3): 140147.

20. Morris R (1984) Developments of a water-maze procedure for studying spatial learning in the rat. J Neurosci Methods 11(1): 47-60.

21. Hooge DR, Deyn P (2001) Application of the Morris water maze in the study of learning and memory. Brain Research Reviews 36(1): 60-90.

22. Joshi H, Mittal Bhadania (2014) Evaluation of freeze dried extract of mentha piperita in management of cognitive dysfunctions in mice. Alzheimer's \& Dementia: The Journal of the Alzheimer's Association 10(4): 461-462.

23. Joshi H, Parle M (2006) Antiamnesic Effects of Desmodium gangeticum in Mice. Yakugaku zasshi 126 (9): 795-804.

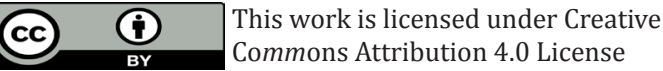

Submission Link: https://biomedres.us/submit-manuscript.php
24. Lee JE, Song HS, Park MN, Kim SH, Shim BS, et al. (2018) Ethanol Extract of Oldenlandia diffusa Herba Attenuates Scopolamine-Induced Cognitive Impairments in Mice via Activation of BDNF, P-CREB and Inhibition of Acetylcholinesterase. Int J Mol Sci 19(2).

25. Morris R (1984) Developments of a water-maze procedure for studying spatial learning in the rat. J Neurosci Methods 11(1): 47-60.

26. Hooge DR, Deyn P (2001) Application of the Morris water maze in the study of learning and memory. Brain Research Reviews 36(01): 60-90.

27. Ellman GL, Courtney KD, Valentino A, Featherstone RM (1961) A new and rapid colourimetric determination of acetylcholinestrase activity. Biochem Pharmacol 7: 88-95.

28. Hanumanthachar Joshi, Majed Abdo Alkanad, Charan CS (2017) Ameliorative Effects of Roots of Asparagus adscendens Roxb. on Cognitive Impairments and Brain Aging Induced By Scopolamine and Diazepam in Animal Models Relevant to Alzheimer's Disease. Journal of Pharmaceutical Research 16(3): 199-207.

29. Hanumanthachar Joshi, Charan CS, Majed Abdo Alkanad (2018) Neuroprotective Potentials of Ayurvedic Rasayana Desmodium triquetrous on Brain Aging and Chemically Induced Amnesia in Animal Models Relevant to Dementia. J Tradit Med Clin 7: 272.

30. Odubanjo VO, Ibukun EO, Oboh G, Adefegha SA (2018) Aqueous extracts of two tropical ethnobotanicals (Tetrapleura tetraptera and Quassia undulata) improved spatial and non-spatial working memories in scopolamine-induced amnesic rats: Influence of neuronal cholinergic and antioxidant systems. Biomed Pharmacother 99: 198-204.

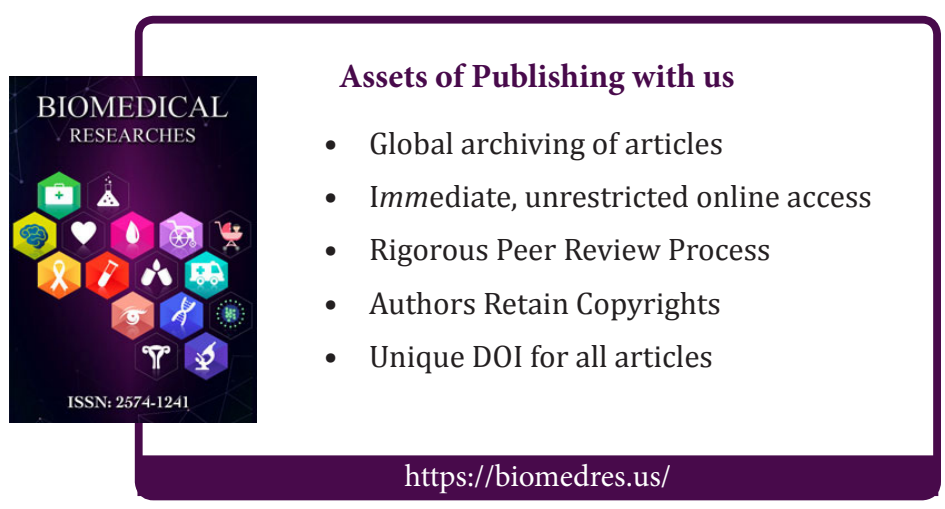

